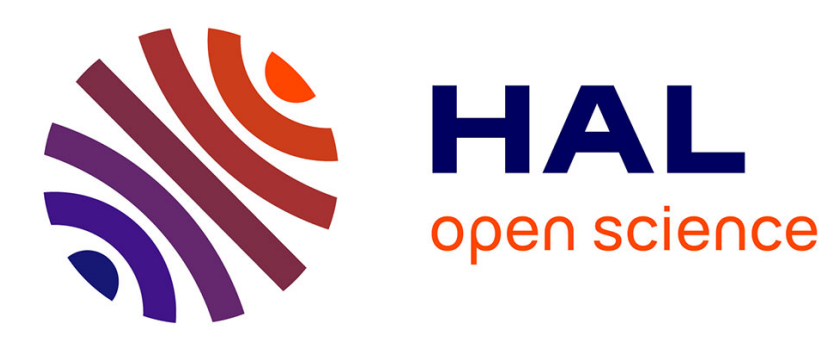

\title{
Skills and Education for Additive Manufacturing: A Review of Emerging Issues
}

\author{
Mélanie Despeisse, Tim Minshall
}

\section{To cite this version:}

Mélanie Despeisse, Tim Minshall. Skills and Education for Additive Manufacturing: A Review of Emerging Issues. IFIP International Conference on Advances in Production Management Systems (APMS), Sep 2017, Hamburg, Germany. pp.289-297, 10.1007/978-3-319-66923-6_34 . hal-01666193

\section{HAL Id: hal-01666193 \\ https://hal.inria.fr/hal-01666193}

Submitted on 18 Dec 2017

HAL is a multi-disciplinary open access archive for the deposit and dissemination of scientific research documents, whether they are published or not. The documents may come from teaching and research institutions in France or abroad, or from public or private research centers.
L'archive ouverte pluridisciplinaire HAL, est destinée au dépôt et à la diffusion de documents scientifiques de niveau recherche, publiés ou non, émanant des établissements d'enseignement et de recherche français ou étrangers, des laboratoires publics ou privés. 


\title{
Skills and Education for Additive Manufacturing: A Review of Emerging Issues
}

\author{
Mélanie Despeisse ${ }^{1}$ and Tim Minshall ${ }^{2}$ \\ ${ }^{1}$ Industrial and Materials Science, Chalmers University of Technology, Sweden \\ melanie.despeisselchalmers.se \\ ${ }^{2}$ Institute for Manufacturing, University of Cambridge, United Kingdom \\ thwm100@cam.ac.uk
}

\begin{abstract}
The recent advances in digital technologies and in additive manufacturing (AM) in particular are revolutionising our industrial landscape. These changes require new engineering and management skills to exploit fully and sustainably the benefits offered by these advanced technologies. The current talent shortage calls for new education programmes to deliver a skilled, capable and adaptable workforce. Existing courses on design, engineering and management related to production and manufacturing do not systematically deliver the necessary skills and knowledge for an effective deployment of AM technologies. Based on a literature review and evidence collected from multi-stakeholder workshops, this paper presents the key themes for education programmes to address the current skill gap and barriers to AM adoption and exploitation.
\end{abstract}

Keywords: Additive manufacturing $\bullet$ DD printing $\bullet$ Education $\bullet$ Skills

\section{Introduction}

\subsection{Background}

Additive Manufacturing (AM), also commonly referred to as 3D printing, was first developed in the 1980s [1,2]. Early AM technologies were mainly used for rapid prototyping and tooling [1]. Recent advances in AM have enabled its use for direct manufacture of components and end-products for a broad range of applications.

AM builds artefacts from CAD models by adding material layer by layer [3], as opposed to conventional machining techniques which are 'subtractive' as they cut material away to obtain the shape desired. The direct use of digital files for manufacturing simplifies the process from design to production, enables the potential for mass customization and can significantly reduce lead times [4,5]. This 'digitalisation' trend in the manufacturing industry is a game changer as (i) current limitations are progressively being removed (e.g. design constraints, centralised manufacturing to achieve economies of scale) and (ii) new limitations emerge (e.g. resource scarcity, cap on waste and emissions).

A new mindset is required for product and process design, manufacturing system configurations and business models more broadly. These new rules of how, where and when products are manufactured, distributed and used are still evolving. Accordingly, 
education programmes need to be adapted [6] and shift towards systems-oriented solutions integrating science, engineering and management principles [7].

\subsection{Current Additive Manufacturing Applications}

The growth of AM utilisation has impacted all sectors of the economy:

Primary sector - raw and intermediate materials for AM. Currently, there are limited options for standard AM materials. In metal powder manufacturing, the powders used for AM are the same standard powders as for other manufacturing techniques such as powder forging, spray deposition, metal injection moulding or hot isostatic pressing. Although it is difficult to tailor materials for AM [8], it is possible and in fact required for some high-value AM produced parts. In addition, powder reclamation for reuse and recycling is a growing sector with particular promises in contributing to a more efficient use of material at systems level.

Secondary sector - additively manufactured products. The most direct impact of AM adoption is on the manufacturing sector, and especially for:

Aerospace. AM is particularly appropriate in aerospace applications as parts are complex, need to be lightweight, high performance, produced in relatively small quantities, and made from advanced, expensive materials. New applications and level of performance present challenges for current (and future) designers and engineers, e.g. new design rules, new materials, new technology, etc.

Automotive. The automotive industry has used AM technologies since the late 80s for rapid prototyping, tooling and custom parts in small production volumes [1], with a recent focus on lightweight materials to improve vehicle fuel efficiency [9].

Medical. AM has been widely used for hearing aids, dental implants and prosthetics. Further applications include with bio-printing to additively manufacture skin tissue and human organs [9]. In the pharmaceutical industry, the technology shows potential to produce custom-made pills to adapt to the patient specific needs, simplifying medication, improving compliance to prescription and reducing risk of medication errors.

Tertiary and quaternary sector - services for AM or services using AM. The service sector has also been impacted by the adoption of AM. Example of AM services include AM machinery sales, leasing, maintenance, upgrade and training; design, manufacturing and delivery as services [4]; development of design libraries providing CAD templates, customized designs; certification, etc.

\section{Research Method}

This research addresses the general need to explore how to make the best out of AM technologies, while avoiding lock-in or unsustainable and irresponsible use of the technology. The work was carried out as part of the 'Bit by Bit' project ${ }^{1}$ and the activities leading to the development of the UK National Strategy for $\mathrm{AM}^{2}$. As part of the AM

\footnotetext{
1 'Bit by Bit: Capturing the Value from the Digital Fabrication Revolution', UK Engineering and Physical Sciences Research Council (EPSRC) award number EP/K039598/1.

${ }^{2}$ http://www.amnationalstrategy.uk/
} 
national strategy process, the main evidence was collected over the period March-October 2015 [10] with additional data gathered during a series of working group sessions in the period November 2015-December 2016, supplemented by desk-based research drawing on secondary sources. The data revealed seven key themes (barriers and opportunities) for AM adoption from a UK perspective [11]. The seven themes identified are highly interconnected and overlap, with a repeated emphasis on the need for skills, education and professional training across almost all the other themes. Thus the skills and education theme was identified as a core issue for the development of the national strategy. Prior to the finalisation of the UK National Strategy itself, an event on 'Identifying and Developing Additive Manufacturing Skills for UK Industry' was held in March 2017 to specifically focus on skills and education, drawing together 80 representatives of a wide range of AM relevant stakeholder organisations.

The next section presents the education and training issues identified to enable the effective deployment of AM technologies in the short to long-term. It does so in three steps: (1) first the barriers and industry needs (skills) for AM were reviewed from the literature and the industry data available, (2) then a review of existing AM courses was conducted, (3) finally, a gap analysis was performed to highlight the key topics that need to be integrated into new education and training programmes.

\section{$3 \quad$ Results}

\subsection{Review of Skills and Industry Needs for AM}

There is a growing body of literature reviewing the barriers and enablers for AM adoption and exploitation [e.g. 8-17]. Some of the work particularly focuses on skills [6,1216]. In addition, a synthesis of the findings from various workshops and surveys $[6,10,11]$ is included to provide a broader view of the issues from industry, government and academic perspectives. A summary of current industry needs is provided in Table 1. It is important to note that the themes often overlap.

Table 1. Themes and perceived barriers to the adoption and exploitation of AM.

\begin{tabular}{|l|l|}
\hline $\begin{array}{l}\text { Issues/ } \\
\text { Themes }\end{array}$ & Summary of industry needs and common perceived barriers \\
\hline $\begin{array}{l}\text { Design \& } \\
\text { modelling } \\
\text { software }\end{array}$ & $\begin{array}{l}\text { Need for design guidelines, modelling software, 3D scanning, education pro- } \\
\text { grammes on design for AM, better understanding of new freedoms and con- } \\
\text { straints, new focus on functionality, availability of AM-skilled designers, secu- } \\
\text { rity of design data. }\end{array}$ \\
\hline $\begin{array}{l}\text { Materials, } \\
\text { processes \& } \\
\text { machines }\end{array}$ & $\begin{array}{l}\text { Understanding properties of different processes, machines, applications, size, } \\
\text { costs, availability (e.g. intellectual property (IP), independent suppliers). Use of } \\
\text { mixed materials with implications for recyclability and biocompatibility. AM- } \\
\text { skilled operators, and importance of post-processing. }\end{array}$ \\
\hline $\begin{array}{l}\text { Skills \& } \\
\text { education }\end{array}$ & $\begin{array}{l}\text { Lack of appropriate skills preventing adoption, up-skilling current workforce vs. } \\
\text { training next generation. Public awareness and education. 3DP in schools, } \\
\text { "teaching the teacher". Balance the provision of generalist and specialist skills } \\
\text { through "mix-and-match" modular programmes. Industry mentoring schemes, } \\
\text { more hands-on teaching methods. Access to open-source learning material. }\end{array}$ \\
\hline
\end{tabular}




\begin{tabular}{|l|l|}
\hline $\begin{array}{l}\text { Quality, } \\
\text { standards \& } \\
\text { testing }\end{array}$ & $\begin{array}{l}\text { Metrology, in-process inspection and controls. Need for data libraries (designs). } \\
\text { Lack of standards for processes, materials, software, products, tests, etc. Gen- } \\
\text { eral vs. sector-specific standards. Tests for higher volumes, non-destructive test- } \\
\text { ing. Quality assurance, certification and liability. }\end{array}$ \\
\hline $\begin{array}{l}\text { Partnerships } \\
\text { \& networks }\end{array}$ & $\begin{array}{l}\text { Regional and national hubs or platforms, collaborative and community-oriented } \\
\text { networks (such as maker spaces) to raise awareness and provide alternative edu- } \\
\text { cational pathways to learn about AM. Ensure that knowledge and emerging in- } \\
\text { dustry needs are captured to teach industry-relevant and up-to-date topics. }\end{array}$ \\
\hline $\begin{array}{l}\text { Creativity \& } \\
\text { innovation }\end{array}$ & $\begin{array}{l}\text { Cross-functional teamwork, ideation techniques and new teaching methods to } \\
\text { foster creativity. Use of 3DP in schools to engage and inspire the next genera- } \\
\text { tion of students. }\end{array}$ \\
\hline $\begin{array}{l}\text { Energy \& } \\
\text { sustainability }\end{array}$ & $\begin{array}{l}\text { Increase the use of AM for green solutions, i.e. renewable and clean energy } \\
\text { such as AM-based materials and components to enhance fuel cell performance. } \\
\text { Need to reduce dependency on fossil resources and the environmental burden of } \\
\text { human activities. Need for life-cycle considerations to assess social and envi- } \\
\text { ronmental impact. }\end{array}$ \\
\hline $\begin{array}{l}\text { Cost \& } \\
\text { financing }\end{array}$ & $\begin{array}{l}\text { Realistic estimate of costs compared to scale of opportunity to allow for viable } \\
\text { business cases. Funding to increase awareness and reduce risk of adoption (e.g. } \\
\text { scale-up, machine purchase) especially for SMEs. Understanding of full costs, } \\
\text { including materials, post-processing and testing. }\end{array}$ \\
\hline IP \& security & $\begin{array}{l}\text { Balance need for openness to share knowledge with need for commercial pro- } \\
\text { tection to capture value from investments, enforcement of IP rights. Current se- } \\
\text { curity, IP and legal systems not appropriate for digital networks. Global IP } \\
\text { leakage. Cyber security concerns preventing rapid AM adoption. }\end{array}$ \\
\hline
\end{tabular}

\subsection{Review of Education and Training Programmes}

A non-exhaustive, exploratory review of existing education programmes - both Continuous Professional Development (CPD) and Higher Education (HE) - was conducted. A total of 45 sources were identified. These include university undergraduate and postgraduate courses, from full programmes to short modules, professional training courses, massive open online courses and downloadable packages. They allowed the key topics being taught in existing programmes to be identified. Table 2 lists these topics along with a description of typical course content and activities.

Table 2. Topics and activities in current AM education and training programmes.

\begin{tabular}{|l|l|}
\hline Topic & Description of typical courses and activities \\
\hline AM fundamentals & $\begin{array}{l}\text { Lectures about advances in AM and production engineering. Learning } \\
\text { about a range of technologies, compatibilities between AM and tradi- } \\
\text { tional techniques (pros \& cons). }\end{array}$ \\
\hline $\begin{array}{l}\text { AM industry } \\
\text { applications }\end{array}$ & $\begin{array}{l}\text { Case studies on current industrial applications. Examples of best prac- } \\
\text { tices. Prototyping, tooling, direct manufacturing, mass customization. }\end{array}$ \\
\hline $\begin{array}{l}\text { Advanced process } \\
\text { engineering }\end{array}$ & $\begin{array}{l}\text { Physical sciences, applied mathematical, advanced engineering design, } \\
\text { material science. Hands-on experience with a variety of AM equipment. } \\
\text { More in-depth understanding of material characteristics, process parame- } \\
\text { ters, and machine designs. Advanced controls and parts testing. Process } \\
\text { optimization. Experiments to explore technology limitations. }\end{array}$ \\
\hline $\begin{array}{l}\text { Design and } \\
\text { modelling }\end{array}$ & $\begin{array}{l}\text { Reverse engineering and 3D laser scanning for direct digital fabrication } \\
\text { purposes. Hands-on labs to design parts on CAD. Design for manufac- } \\
\text { ture, material-specific design principles and qualification approaches. } \\
\text { Design software options for designers. Ergonomics in design. }\end{array}$ \\
\hline
\end{tabular}




\begin{tabular}{|l|l|}
\hline $\begin{array}{l}\text { Production econom- } \\
\text { ics \& business man- } \\
\text { agement }\end{array}$ & $\begin{array}{l}\text { Method to improve productivity and reduce manufacturing costs. Ensure } \\
\text { products and services delivered to industry at the quality and time re- } \\
\text { quired. Inventory management. }\end{array}$ \\
\hline $\begin{array}{l}\text { Management and } \\
\text { communication }\end{array}$ & $\begin{array}{l}\text { Teamwork, problem-solving skills, critical and analytical skills, commu- } \\
\text { nication and management skills. }\end{array}$ \\
\hline $\begin{array}{l}\text { Research \& } \\
\text { development }\end{array}$ & $\begin{array}{l}\text { Lab-based R\&D in measurement methods, models, instrumentation, sen- } \\
\text { sors and data. Improve scientific understanding of AM. Advances in pro- } \\
\text { cess controls, equipment and material properties. Industry-focused re- } \\
\text { search project with novel processes, materials and simulation. }\end{array}$ \\
\hline
\end{tabular}

\subsection{Summary of Skills for AM and Suggestions for Education Programmes}

The list of topics taught in programmes available (section 3.2) was compared to needs collected from the literature and industry (section 3.1) to identify the gaps in current programmes available. The first observation was that there is still a relatively low number of AM programmes available. It shows that (1) AM is not systematically taught in design and engineering curricula within universities, and (2) few institutions are proposing specialised courses for AM. The second observation was that, while most courses focused on technical aspect, some topics around softer issues are poorly covered (if at all); e.g. IP, liability, quality assurance, sustainability and business models specially as they relate to AM.

In summary, the following recommendations are made to enhance the AM skills for designers, engineers and managers:

- Recognise AM as a family of technologies. Appreciate the value of AM as tool for manufacturing along more traditional techniques, and as an enabler of innovation (see design considerations below).

$>$ Know when to use AM (and when not) by considering other manufacturing techniques and their respective strengths and limitations. AM may not be the best solution: other traditional or mixed / hybrid methods could work better, be cheaper, more efficient, result in better quality products, etc.

$>$ Need to understand the appropriateness of various manufacturing techniques for different materials and applications.

$>$ Need for new process controls and quality assurance methods.

- Effectively design products for AM by shifting focus and using new tools.

$>$ New levels of performance achieved through AM with innovative solutions based on new design thinking (focus on functionality, performance, quality).

$>$ Designing for AM requires new design approaches and modelling software, e.g. 3D scanning, new design freedoms and structures.

$>$ New design guidelines should include considerations for emerging constraints, e.g. limited availability of AM materials, resource scarcity for rare metals, design for modularity, upgradability, disassembly, recycling, etc. (principles of design for the environment).

- Understand AM processes and materials and their broader implications on the value chain and business model.

$>$ Economics of AM go beyond basic machine and material cost.

$>$ Need for basic understanding of legal (e.g. IP, cyber security) and liability issues (e.g. quality assurance and insurance) surrounding AM utilisation. 
Need for more responsible models of production and consumption (sustainable products and services) through innovative business models.

$>$ Need to consider the full impacts of AM from a life cycle perspective. It is currently challenging to assess the sustainability of AM technology due to the lack of tools and methods to do so.

- Acknowledge that AM technology is evolving quickly so the limitations we see today may very well be removed the next year.

$>$ AM creates new opportunities, new business models, new jobs, etc.

$>$ Need to prepare current and next generation to respond effectively and keep an open-mind as the rate of technological change is accelerating.

$>$ Need to quickly adapt and update programmes to technology progress.

$>$ Need to "teach the teachers" to avoid spreading misunderstanding and misperception of AM technologies and capabilities.

- Balance the provision of generalist skills and knowledge as well as more advanced courses for specialists.

$>$ Promote distributed and modular models for all educational levels.

$>$ Need for open-access, free, online resources.

$>$ Need for regional and national platforms and community-oriented networks (such as maker spaces) to raise awareness and provide alternative educational pathways to learn about AM.

- Prepare students for jobs in industry and support incumbent workers by ensuring that AM courses and programmes are up-to-date and easy access.

$>$ Raise awareness among the public and provide easy access to training programs for workers and students by establishing collaborative and communityoriented networks for AM awareness and education (i.e. above-mentioned alternative ways to learn about AM).

> Support educational programs in STEAM (STEM + arts) and across a wide range of learning environments to provide industry-relevant knowledge and experience, e.g. tutoring, industry-based projects, lab-based activities.

$>$ Need for new partnerships and innovation centres bringing industry and academic institutions to keep education and research relevant and closely linked to industry needs.

\section{Conclusions}

Research is still on-going to better understand the business opportunities created by AM as well as barriers to realise the full benefits of AM. The challenges encountered by industry in effectively using the technology are not fully understood. This paper attempts to capture the current state of these industry challenges and barriers to AM adoption which should be addressed by education programmes. Industry needs and challenges were categorised and linked to specific sets of skills for AM. We then reviewed existing education programmes and compared their content to the industry needs to characterise the skills gap for AM adoption and exploitation. Finally, we made some initial recommendations for developing new education and training programmes to support the provision of AM-skilled designers, engineers and managers. 
The review of education programmes revealed that there are some courses available providing AM content covering a broad range of issues as identified in the review of industry needs. However the number of programmes available is low compared to today's high demand for AM skills. In addition, there are increasing concerns about the content of these courses: Do they provide the necessary skills and knowledge to realise the full potential of the technology? There is an urgent need to develop university and other training programmes to increase awareness and educate the next generation of workers and students in productive utilisation of AM technologies and generate some societal "pull" for AM technologies [17].

Some of the most commonly mentioned barriers are lack of AM-specific design skills, limited working materials, uncertainties in part qualification, lack of metrology and production standards. Besides these technical barriers to AM adoption reported mainly in the literature, there is a clear need to better educate future engineers as unfamiliarity with AM technologies is recognised as a major barrier for industrial adoption. Finally, some of the issues poorly covered as highlighted in bold in Fig. 1. Further work is still needed to consolidate the findings and recommendations made in this paper.

Fig. 1. Mindmap of recommendations for AM education and training.

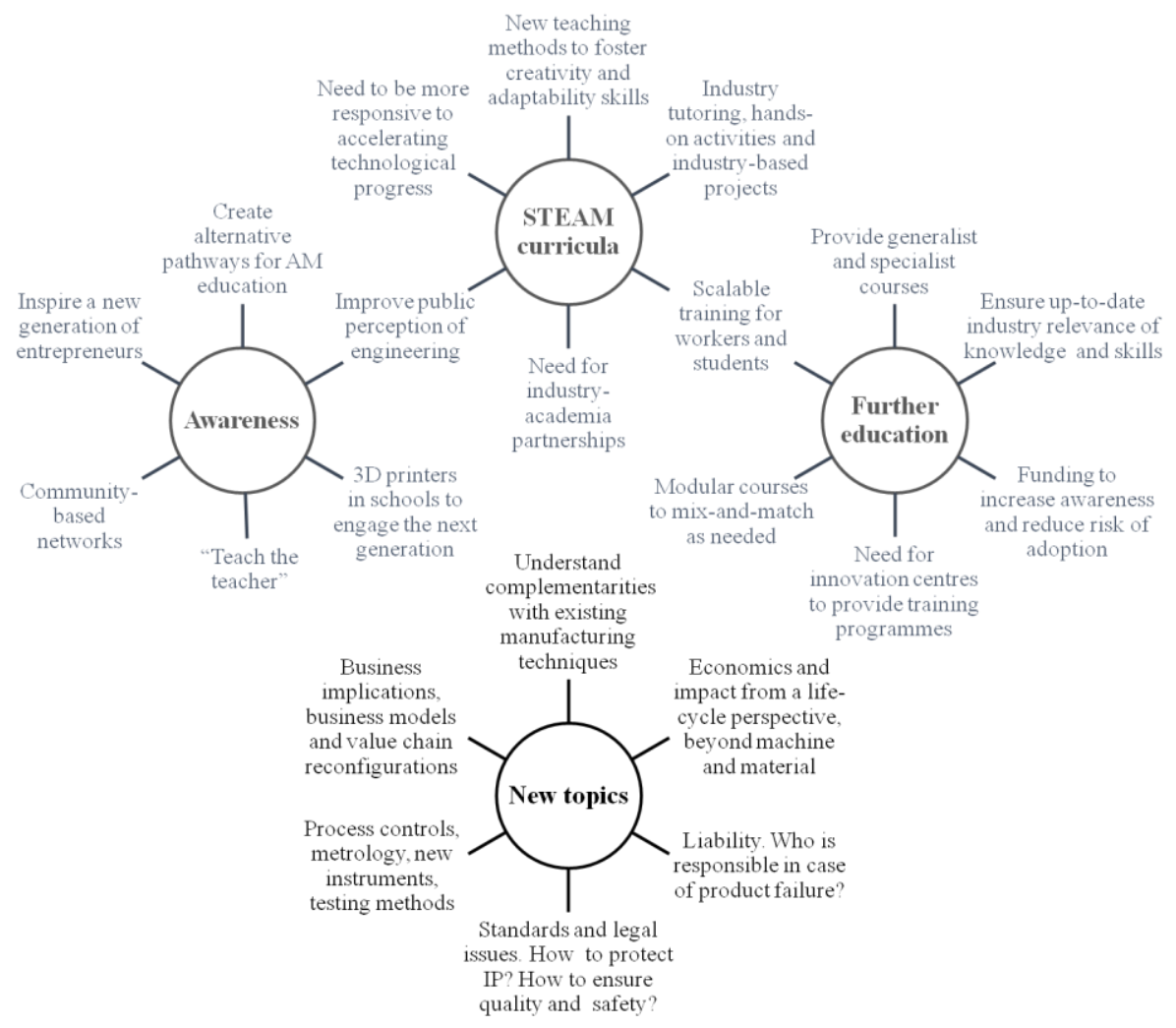




\section{Acknowledgments}

This research was carried out as part of the UK Engineering and Physical Sciences (EPSRC) funded project entitled 'Bit by Bit: Capturing the Value from the Digital Fabrication Revolution', EP/K039598/1.

\section{References}

1. Langdon, R., 1997. A decade of rapid prototyping. Automotive Engineer 22(4), pp.44-59.

2. Kruth, J.-P. , Leu, M.C. Nakagawa, T., 1998. Progress in Additive Manufacturing and Rapid Prototyping. CIRP Annals - Manufacturing Technology 47(2), pp. 525-540.

3. ASTM, 2012. ASTM F2792e12a: Standard Terminology for Additive Manufacturing Technologies. ASTM International, West Conshohocken, PA.

4. Weller, C., Kleer, R., Piller, F.T. 2015. Economic implications of 3D printing: Market structure models in light of additive manufacturing revisited. International Journal of Production Economics 164, pp. 43-56.

5. Atzeni, E., Salmi, A., 2012. Economics of additive manufacturing for end-usable metal parts. International Journal of Advanced Manufacturing Technology 62(9-12), pp. 11471155.

6. Simpson, T.W., Williams, C.B., Hripko, M., 2017. Preparing industry for additive manufacturing and its applications: Summary \& recommendations from a National Science Foundation workshop. Additive Manufacturing 13, pp. 166-178.

7. Swearengen, J.C., Barnes, S., Coe, S., Reinhardt, C., Subramanian, B., 2003. Globalization and the undergraduate manufacturing engineering curriculum. Journal of Engineering Education 91(2), pp. 255-261.

8. Gu, D.D., Meiners, W., Wissenbach K., Poprawe, R., 2012. Laser additive manufacturing of metallic components: materials, processes and mechanisms. International Materials Reviews 57(3), pp. 133-164.

9. Guo, N., Leu, M.C., 2013. Additive manufacturing: Technology, applications and research needs. Frontiers of Mechanical Engineering 8(3), pp. 215-243.

10. Dickens P and Minshall T 2015. Update Report 1: How Was The Evidence Collected?

11. Dickens $P$ and Minshall $T$ 2015. Update Report 2: What Did The Initial Evidence Reveal?

12. Gao, W., Zhang, Y., Ramanujan, D., Ramani, K., Chen, Y., Williams, C.B., Wang, C.C.L., Shin, Y.C., Zhang, S., Zavattieri, P.D., 2015. The status, challenges, and future of additive manufacturing in engineering. Computer Aided Design 69, pp. 65-89.

13. Ford, P., Dean, L., 2013. Additive Manufacturing in Product Design education: Out with the old in and in with the new? Proceedings of the 15th International Conference on Engineering and Product Design Education (EPDE 2013), pp. 611-616.

14. Junk, S., Schrock, S., 2016. New developments in design education for additive manufacturing. Proceedings of the 18th International Conference on Engineering and Product Design Education (EPDE 2016), pp. 290-295.

15. Williams, C.B., Seepersad, C.C., 2012. Design for additive manufacturing curriculum: A problem- and project-based approach. Proceedings of the 23rd Annual International Solid Freeform Fabrication Symposium (SFF 2012), pp. 81-92.

16. Minetola, P., Iuliano, L., Bassoli, E., Gatto, A., 2015. Impact of additive manufacturing on engineering education - evidence from Italy. Rapid Prototyping Journal 21(5), pp. 535-555.

17. Bourell, D.L., Leu, M.C., Rosen, D.R., 2009. Roadmap for Additive Manufacturing: Identifying the Future of Freeform Processing. The University of Texas at Austin. 